\title{
$\nabla$
}

\section{Comparative analysis of the quality of life of patients with discoid lupus erythematosus and systemic lupus erythematosus with skin injuries}

Análise comparativa da qualidade de vida de pacientes portadores de lúpus eritematoso discóide e lúpus eritematoso sistêmico com lesões cutâneas

\author{
Priscila Reis Martins ${ }^{1}$ \\ Thiago Augusto Ferrari ${ }^{1}$ \\ Bruna Fabiana Vianna Alessio ${ }^{1}$
}

\author{
Thelma Skare ${ }^{2}$ \\ Ana Paula Franchetti Silva ${ }^{1}$
}

\begin{abstract}
Lupus erythematosus is an autoimmune disease of unknown etiology with cutaneous and vascular lesions. Both discoid lupus erythematosus (DLE) and systemic lupus (SLE) affect the skin. Visible skin lesions in young women can cause loss of self esteem. In the present study we aimed to evaluate and compare the quality of life in SLE and LED through an observational study of 64 patients. These patients were divided into 2 groups: Group 1: SLE $(n=38)$; group 2: DLE $(n=26)$ and then completed the quality of life questionnaire - Dermatology Life Quality Index or DLQI. It was found that patients with DLE have a worse quality of life than patients with SLE. It is believed that this fact is generated by the difference in the spectrum of injuries.

Keywords: Dermatology; Lupus erythematosus, cutaneous; Lupus erythematosus, discoid; Lupus erythematosus, systemic; Quality of life

Resumo: Lúpus eritematoso é uma doença auto-imune de etiologia desconhecida, com lesões cutâneovasculares. Tanto o Lúpus Eritematoso Discóide (LED) como o Sistêmico (LES) acometem a pele. Lesões cutâneas visíveis em mulheres jovens podem causar perda de auto estima. No presente estudo procurou-se avaliar e comparar a qualidade de vida em 64 pacientes com LED e LES através de um estudo observacional. Esses pacientes foram divididos em 2 grupos: Grupo 1: LES $(n=38)$; grupo 2: LED $(\mathrm{n}=26)$. A seguir aplicou-se o questionário de qualidade de vida - Dermatology Life Quality Índex ou DLQI. Verificou-se que pacientes com LED têm pior qualidade de vida que pacientes com LES Acredita-se que este fato seja gerado pela diferença no espectro de suas lesões.

Palavras-chave: Dermatologia; Lupus eritematoso cutâneo; Lupus eritematoso discóide; Lúpus eritematoso sistêmico; Qualidade de vida
\end{abstract}

Received on 19.10.2010.

Approved by the Advisory Board and accepted for publication on 25.04.2011.

* Work performed at the Services of Rheumatology and Dermatology of the Hospital Universitário Evangélico de Curitiba - Faculdade Evangélica do Paraná (HUEC-FEPAR) - Curitiba (PR), Brazil.

Conflict of interest: None

Financial funding: None

Graduate at the Faculdade Evangélica do Paraná (FEPAR) - Curitiba (PR), Brazil.

Assistant Teacher of Rheumatology at the Medicine Course of the Faculdade Evangélica do Paraná (FEPAR) - Curitiba (PR), Brazil. 
Lupus erythematosus is a disease characterized by a broad spectrum of cutaneous lesions. ${ }^{1}$ Discoid lesions can develop both on the purely cutaneous DLE and SLE. ${ }^{1}$ DLE and SLE develop mostly in young women, in whom the consequences, from the cosmetic point of view, are well valued, and are detrimental to their quality of life. The appreciation of these aspects can be totally different in the two populations, and this research was conducted to understand them.

This work was approved by the local Research Ethics Committee and the participants signed the consent form. It was an observational, cross-sectional work conducted along the months of July/2009 to July/2010, when participants seen at the rheumatology and the dermatology outpatient's clinic of a university hospital were selected, according to consultation order. Patients from both sexes, over the age of 18 years, with a diagnosis of DLE by skin biopsy or of SLE by fulfilling the 4 criteria from the American College of Rheumatology for this disease were included. ${ }^{2}$ Individuals with mental inability to understand to questionnaire and those with SLE without cutaneous lesions, with purely subacute lupus and presenting with concomitant skin diseases were excluded. 64 patients were included, 38 with SLE and 26 with DLE. All of them answered the Dermatology Life Quality Index (DLQI), which has ten questions related to the patient's last week. ${ }^{3}$ Questions from the DLQI can be subdivided into six different domains: symptoms and feelings regarding the disease, daily activities, leisure, work, and school, interpersonal relationship and treatment. Each domain has a score from 0 (no interference) to 3 (a lot of interference). This way, the DLQI varies from 0 to 30 , where the values $0-1$ do not interfere; from 2-5 interfere a little; from 6-10 interfere moderately; from 11-20 interfere a lot and above 21 interfere very much with the quality of life. ${ }^{4}$ The data was grouped in tables of frequency and contingency. For the study of the association of the nominal data the chi-square and Fisher tests were used, and for the numerical data the Mann Whitney test was used, with the help of the GraphPad Prism software, version 4.0. The level of significance was set at 5\%.

From the 38 patients with SLE that took part on the study 36 were women and 2 men and the average age was 34 years. In terms of schooling, 31.6\% completed fundamental school, $47.4 \%$ middle school and $15.7 \%$ completed higher education. From the 26 patients with DLE one was male and the others were female, and the average age was 45 years. In this subgroup, $38.4 \%$ completed fundamental school, $53.8 \%$ middle school and $7.7 \%$ higher education. The average duration of the disease was 6 years in both groups. In the SLE group $47.3 \%$ of the cases had renal lesions; 21.05\% had arthritis; $18.2 \%$ had mood disturbances;
$5.2 \%$ had cardiac involvement and 5.2\% had neurological involvement. All patients with SLE presented with some form of cutaneous lesion and this form was discoid in $18.4 \%$. No patient had lesions of subacute lupus.

The scores obtained with the application of the DLQI varied from 0 to 27 points (average $6.5 \pm 6.02$ points) from the patients with SLE and from 1 to 23 (average $12.42 \pm 6.24$ points) from those with DLE, where $\mathrm{p}=0.0004$. Chart 1 shows data from the scoring of the patients with SLE and DLE according to the level of interference on their quality of life.

As for the domains studied by the DLQI, the one related to the symptoms and feelings in regards to the disease was the one which interfered most with the life of both patients with SLE (1.22) and with DLE (1.78). Work and school was the domain with the second highest impact on patients with both types of lupus; however, DLE had a higher scoring than SLE in all the criteria.

On the SLE sample, when comparing the scores on those with and without discoid lesions, no difference was observed $(\mathrm{p}=0.50)$; however, when analyzing SLE patients with and without mood disturbances there was a tendency for a higher DLQI scoring in those with mood disturbances $(p=0.065)$.

In this analysis we observed that patients with DLE scored an average of 12 points on the DLQI, values comparable to those of psoriasis and atopic dermatitis, which shows the important repercussion of the disease on the quality of life of the patients. When comparing the groups, the patients with DLE had a worse quality of life than those with SLE, despite the latter being more severe. Some explanations can be suggested in this case. The first is the difference on the spectrum of the cutaneous lesions; in DLE they have a worse cosmetic effect; on the systemic the acute lesions are fleeting and disappear without

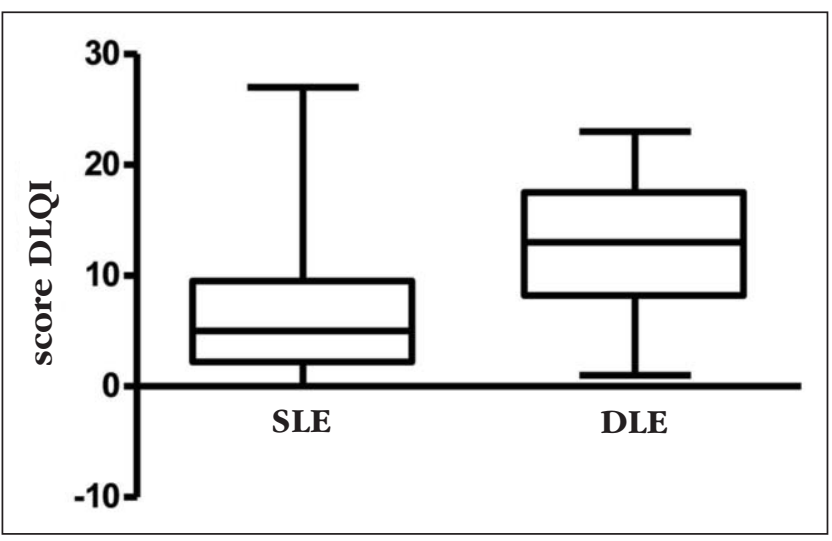

CHART 1: Comparison of the DLQI scores amongst patients with SLE and DLE $(p=0.0004)$ 
marks. Against this hypothesis is the fact that patients with SLE with and without discoid lesions did not show differences on the DLQI. Another possible explanation is that the highest preoccupation with a serious systemic disease on the SLE group would minimize the importance given to the cutaneous aspect itself, leading to a better adaptation to the disease and a small impact on the quality of life in this group.

\section{REFERENCES}

1. Fabbri P, Cardinali C, Giomi B, Caproni M. Cutaneous lupus erythematosus: diagnosis and management. . Am J Clin Dermatol. 2003;4:449-65.

2. Hochberg MC. Updating the American College of Rheumatology revised criteria for the classification of systemic lupus erythematosus. Arthritis Rheum 1997;40:1725.

3. Zogbi H, Muller MC, Protas JS, Kieling CM, Driemeier FM. Adaptação e validação DLQI (Dermatology Life Quality Index) para uma amostra brazileira: avaliando qualidade de vida em dermatologia. PsiqWeb [Internet]. 2004 [acesso 15 Ago. 2010]. Disponível em: http://www.psiqweb.med.br/site/.

4. Martins BDL, Torres FN, Oliveira MLWDR. Impacto na qualidade de vida em pacientes com hanseníase: correlação do Dermatology Life Quality Index com diversas variáveis relacionadas à doença. An Bras Dermatol. 2008,83:39-43.

5. Coghi S, Bortoletto MC, Sampaio AP, Andrade HFJ, Aoki V. Quality of life is severly compromised in adult patients with atopic dermatitis in Brazil. Clinics. 2007;62: 235-42.

\author{
MAILING ADDRESS: \\ Priscila Reis Martins \\ Hospital Universitário Evangélico de Curitiba \\ Alameda Augusto Stellfeld, 1908 - Bigorrilho \\ 80730-150 Curitiba, PR \\ E-mail:prizinba25@botmail.com
}

How to cite this article: Martins PR, Skare T, Ferrari TA, Silva APF, Alessio BFV. Comparative analysis of the quality of life of patients with discoid lupus erythematosus and systemic lupus erythematosus with skin injuries. An Bras Dermatol. 2012;87(2):326-8. 